\title{
Article \\ Effect of Shot Peening on the Evolution of Scale on T91 Steel Exposed to Steam
}

\author{
Liming $\mathrm{Xu}^{1}$, Yinsheng $\mathrm{He}^{2}$, Yeonkwan Kang ${ }^{2}$ and Keesam Shin ${ }^{1, *}$ \\ 1 School of Materials Science and Engineering, Changwon National University, Changwon 51140, Korea; \\ xulimings2016@gmail.com \\ 2 KEPCO Research Institute, Korea Electric Power Corporation, Munji-ro, Yusung-Gu, Daejeon 34056, Korea; \\ Yinshenghe@gmail.com (Y.H.); yeonkwan.kang@kepco.co.kr (Y.K.) \\ * Correspondence: keesam@changwon.ac.kr; Tel.: +82-55-213-3690; Fax: +82-55-261-7017
}

Citation: Xu, L.; He, Y.; Kang, Y.; Shin, K. Effect of Shot Peening on the Evolution of Scale on T91 Steel Exposed to Steam. Appl. Sci. 2021, 11, 8831. https://doi.org/10.3390/ app11198831

Academic Editor: José A. F. O. Correia

Received: 20 August 2021

Accepted: 16 September 2021

Published: 23 September 2021

Publisher's Note: MDPI stays neutral with regard to jurisdictional claims in published maps and institutional affiliations.

Copyright: (c) 2021 by the authors. Licensee MDPI, Basel, Switzerland. This article is an open access article distributed under the terms and conditions of the Creative Commons Attribution (CC BY) license (https:// creativecommons.org/licenses/by/ $4.0 /)$.

\begin{abstract}
Shot peening can be an effective solution for the prevention or retardation of scale formation, and subsequent exfoliation, upon exposure of the inner tube to steam in coal-fired power plants. In this study, specimens of T91 tubes were shot peened and then exposed to 1-bar steam for 100-1000 h at $650{ }^{\circ} \mathrm{C}$, and were then analyzed using Vickers hardness test and microscopic techniques OM, SEM, TEM, etc. The analysis indicates that the oxide scales are typically $\mathrm{Fe}_{2} \mathrm{O}_{3}$ on the topmost layer, $\mathrm{Fe}_{3} \mathrm{O}_{4}$ below, and a $\mathrm{FeCr}_{2} \mathrm{O}_{4}$ spinel on the bottom in both shot peening treated and untreated specimens. However, the oxide scale thicknesses of shot peened specimens are thinner, indicating that shot peened specimens have better oxidation resistance. In addition, numerous defects, such as voids and micro-cracks, were found in the untreated specimens, which are believed to cause exfoliation of the uppermost $\mathrm{Fe}_{2} \mathrm{O}_{3}$ layers of the specimens exposed to steam for 800 and $1000 \mathrm{~h}$. By contrast, the shot peened specimens maintained a dense contact oxide scale with fewer defects.
\end{abstract}

Keywords: T91; shot peening; steam oxidation; scale separation

\section{Introduction}

Owing to their microstructural stability, high temperature strength, and oxidation resistance, $9 \mathrm{Cr}$-1Mo ferritic-martensitic (F-M) steels are universally found in high temperature applications in fossil fuel power plants. During exposure to high temperature steam environments, oxidation is an unavoidable problem for boiler tubes, such as found in superheaters and reheaters [1,2].

The oxidation behavior of F-M steels has been investigated by several groups [3-5], and are dependent on various factors, including temperature, atmosphere, and oxygen concentration. Tan et al. [6] reported that the oxide scale with a three-layer microstructure composed of $\mathrm{Fe}_{2} \mathrm{O}_{3}, \mathrm{Fe}_{3} \mathrm{O}_{4}$ and $(\mathrm{Fe}, \mathrm{Cr})_{3} \mathrm{O}_{4}$ formed on T91 steel in an $\left(\mathrm{Ar}+\mathrm{H}_{2} \mathrm{O}\right)$ atmosphere at $600-700{ }^{\circ} \mathrm{C}$. The difference in the coefficients of thermal expansion (CTE) of $\mathrm{Fe}_{2} \mathrm{O}_{3}\left(12.5 \times 10^{-6} \mathrm{~K}^{-1}\right.$ at $\left.100-1200{ }^{\circ} \mathrm{C}\right)$ and $\mathrm{Fe}_{3} \mathrm{O}_{4}\left(18.8 \times 10^{-6} \mathrm{~K}^{-1}\right.$ at $\left.300-800{ }^{\circ} \mathrm{C}\right)$ result in partial exfoliation of outer $\mathrm{Fe}_{2} \mathrm{O}_{3}$ layer. The studies by Chen et al. [5] indicated that the oxide scales of T91 steel exhibited higher thickness, higher interconnected porosity, and weak adhesion to metal matrix for high oxygen concentration exposure. According to Wagner's theory of oxidation [7], the oxidation rate depends highly on the diffusion of the ions across the oxide scale during the steady state of oxidation.

Shot peening is a widely used method to cause plastic deformation at the surface, resulting in high-density dislocations and refined grains [8]. Shot peening improves oxidation resistance due to the increased number of pathways for $\mathrm{Cr}$ to diffuse to the surface to form a Cr-rich protective layer. An inner Cr-rich protective layer of $\mathrm{Cr}_{2} \mathrm{O}_{3}$ and $\mathrm{FeCr}_{2} \mathrm{O}_{4}$ has been observed in both $\mathrm{P92}$ and $\mathrm{SS} 304 \mathrm{H}$ steel [9-11]. Similar results were also reported by J. Kurley and B. Pint [12]: a protective $\mathrm{Cr}$ - and Mn-rich oxide layer improved the steam oxidation resistance, forming a thinner oxide scale, and showing less mass 
change of $304 \mathrm{H}$ at $550-625^{\circ} \mathrm{C}$. However, this benefit began to break down after $\sim 5000 \mathrm{~h}$ exposure at $650^{\circ} \mathrm{C}$.

Thus, an investigation of the formation and evolution of oxide scales in the early stage of steam oxidation is called for. In this study, we characterize the features of oxidation behavior of T91 steel after short-term steam exposures of 100-1000 h.

\section{Materials and Methods}

T91 boiler tube steels were purchased from "ILJIN Steel" with outer diameter of $50.8 \mathrm{~mm}$ and wall thickness of $6.5 \mathrm{~mm}$. The as-received tubes were cut into $15 \times 10 \times 2 \mathrm{~mm}^{3}$ pieces and mechanically polished to \#2000 grit-finish before ultrasonic shot peening (SP) and subsequent steam exposure. Steam was generated by heating distilled water to $\sim 650{ }^{\circ} \mathrm{C}$; it was then blown across the sample surface for 100, 200, 400, 600, 800, and $1000 \mathrm{~h}$. further details of the steam exposure are available in reference [10]. The shot peening conditions and specimen list are presented in Table 1.

Table 1. Shot peening and steam exposure conditions of T91 specimens.

\begin{tabular}{|c|c|c|c|c|c|c|}
\hline \multirow{2}{*}{$\begin{array}{l}\text { Shot Peening } \\
\text { Treatment }\end{array}$} & Ball Size & & Amplitude & Frequency & & Duration \\
\hline & $2.0 \mathrm{~mm}$ & & $50 \mu \mathrm{m}$ & $20 \mathrm{kHz}$ & & $10 \mathrm{~min}$ \\
\hline \multirow{2}{*}{$\begin{array}{l}\text { Steam exposure } \\
\text { durations }\end{array}$} & \multicolumn{6}{|c|}{ Test durations } \\
\hline & $100 \mathrm{~h}$ & $200 \mathrm{~h}$ & $400 \mathrm{~h}$ & $600 \mathrm{~h}$ & $800 \mathrm{~h}$ & $1000 \mathrm{~h}$ \\
\hline
\end{tabular}

The chemical composition of the T91 tubes was measured by optical emission spectrometry (OES, mode ARL-3460), and is given in Table 2. The morphology, elemental distribution, and phase distribution of the oxidation scale were determined by SEM (JSM6510, equipped with INCA EDS, operated at an accelerating voltage of $20 \mathrm{kV}$ ), FE-SEM (EBSD, TESCAN MIRA II LMH equipped with TSL OIM components with the depth beam scan mode), XRD (Rigaku SmartLab, operated at a tube voltage and current of $45 \mathrm{kV}$ and $200 \mathrm{~mA}$ ), and TEM (Philip CM200-FEG, operated at an accelerating voltage of $200 \mathrm{kV}$ ). Specimens for SEM/EBSD analysis were prepared by mechanical polishing with \#2000 grit and subsequent final polishing with a $0.05 \mu \mathrm{m}$ colloidal silica suspension for $1 \mathrm{~h}$. Specimens for TEM observation were prepared by Struers TenuPol- 5 twin jet polishing system. The microhardness was measured by a Vickers hardness tester (Future-Tech Model FM-7E) on the polished cross section with $1 \mu \mathrm{m}$ metallographic polishing cloth. Then the hardness of each depth was tested for five times on the load of $200 \mathrm{gf}$.

Table 2. Nominal and measured chemical composition (wt. \%) of the T91.

\begin{tabular}{cccccccccccccc}
\hline Elements & $\mathbf{C}$ & $\mathbf{S i}$ & $\mathbf{M n}$ & $\mathbf{P}$ & $\mathbf{S}$ & $\mathbf{N i}$ & $\mathbf{C r}$ & $\mathbf{M o}$ & $\mathbf{N}$ & $\mathbf{A l}$ & $\mathbf{N b}$ & $\mathbf{V}$ & $\mathbf{F e}$ \\
\hline $\begin{array}{c}* \text { T91 } \\
\begin{array}{c}\text { tandard } \\
* \text { OES } \\
\text { measured }\end{array}\end{array}$ & $0.07 \sim 0.14$ & $0.20 \sim 0.50$ & $0.30 \sim 0.60$ & $\leq 0.020$ & $\leq 0.010$ & $\leq 0.40$ & $8.00 \sim 9.50$ & $0.85 \sim 1.05$ & $0.03 \sim 0.07$ & $\leq 0.02$ & $0.06 \sim 0.10$ & $0.18 \sim 0.25$ & Bal. \\
\hline
\end{tabular}

* T91 = ASTM-A213, ${ }^{* *}$ OES: optical emission spectrometry.

\section{Results}

\subsection{Effect of Shot Peening on Microstructure PRIOR to Steam Exposure}

The equiaxed grain and uniformly distributed $\mathrm{M}_{23} \mathrm{C}_{6}$ precipitates were observed in the original T91 specimen, as shown in Figure 1. Shot peening causes plastic deformation near the surface, hence it changes the microstructure and surface properties. Microstructural investigation of untreated and SP-treated specimens was performed by SEM and EBSD. Figure 2 shows the effect of shot peening on the surface microstructure. The original equiaxed grains in the untreated specimens are $\sim 10 \mu \mathrm{m}$, as shown Figure 2a. The presence of smaller grains near the shot peened surface and a gradual increase in the grain size towards the core of the materials validates the grain refinement effect of the shot peen- 
ing, which is shown in Figure 2c, where the grain size near the shot peened surface is $\sim 3 \mu \mathrm{m}$. The refinement of the grains is likely to improve the hardness according to the Hall-Petch relationship. To characterize the surface hardening effect of the shot peening, the Vickers hardness was measured. The Vickers hardness of the topmost surface was $\sim 250 \mathrm{HV}$, decreasing to the original value of $\sim 216 \mathrm{HV}$ with increasing depth as shown in Figure 3. During plastic deformation in shot peening, precipitates might also be refined, resulting in an increase in number density as reported for $\mathrm{M}_{23} \mathrm{C}_{6}$ [8].

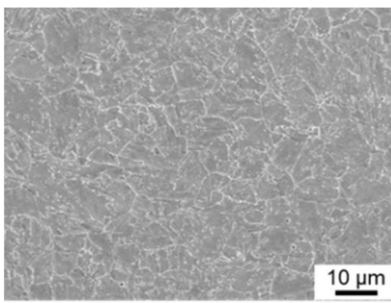

(a)

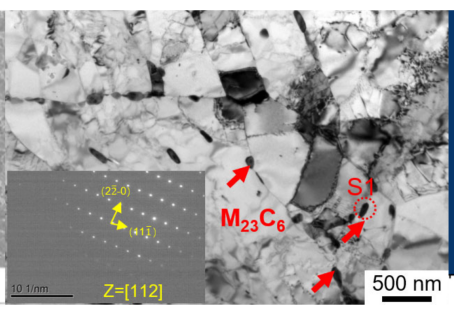

(b)

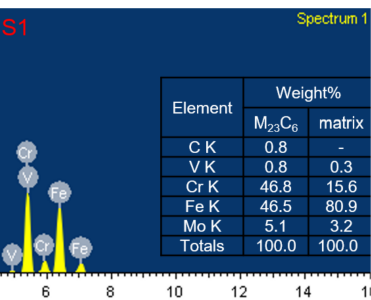

(c)

Figure 1. Microstructure of the T91 specimens: (a) SEM and (b) TEM with corresponding SADP of S1, and (c) EDS results of S1 before shot peening.

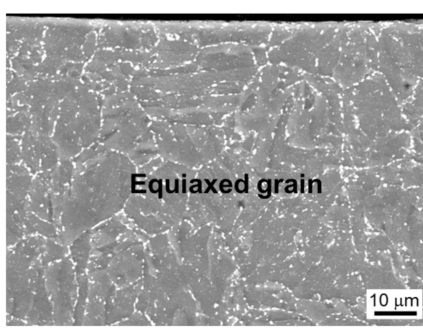

(a)

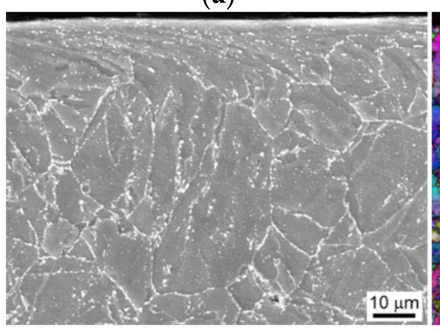

(c)

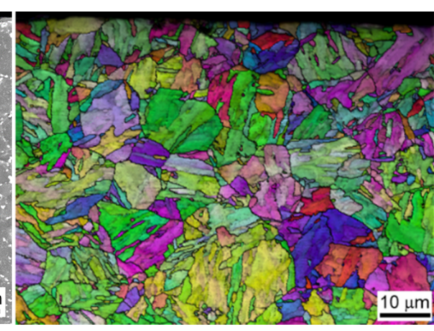

(b)

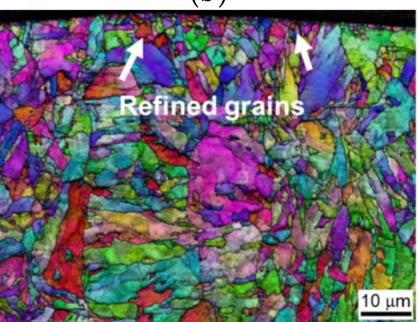

(d)
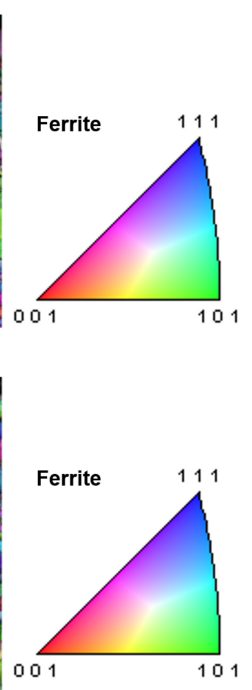

Figure 2. Surface microstructure of the specimens before steam oxidation: $(\mathbf{a}, \mathbf{b})$ SEM and EBSD IPF with orientation map of the untreated specimen, $(\mathbf{c}, \mathbf{d})$ SEM and EBSD IPF with orientation map of the shot peened specimen.

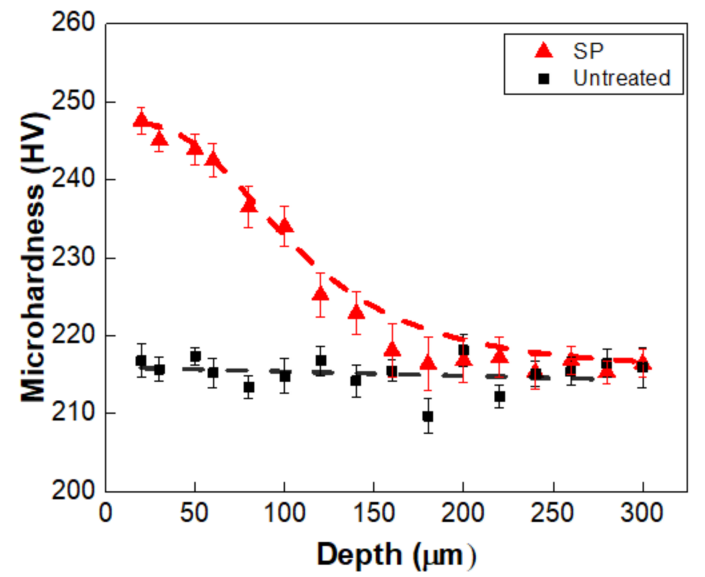

Figure 3. Microhardness of T91 untreated (black squares) and shot peened (red triangles) specimens. 


\subsection{Characteristics of the Oxidation Scale}

Figure 4 shows cross-sectional EBSD micrographs of untreated and shot peened specimens after steam exposure at $650{ }^{\circ} \mathrm{C}$ for $200 \mathrm{~h}$. The phase identification revealed that the oxides are $\mathrm{Fe}_{2} \mathrm{O}_{3}$ in the top layer, followed by $\mathrm{Fe}_{3} \mathrm{O}_{4}$ layer and then a $\mathrm{Fe}-\mathrm{Cr}-\mathrm{O}$ spinel layer, which agrees with the oxidation scale structure reported by Chen et al. [5].

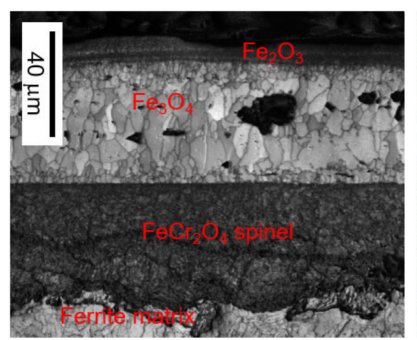

(a)

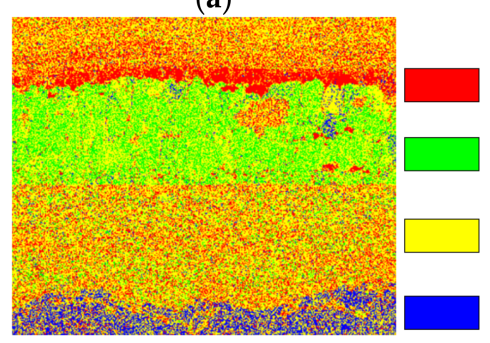

(c)

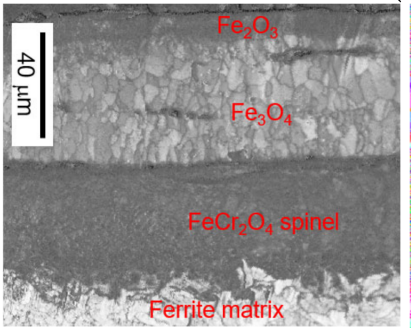

(d)

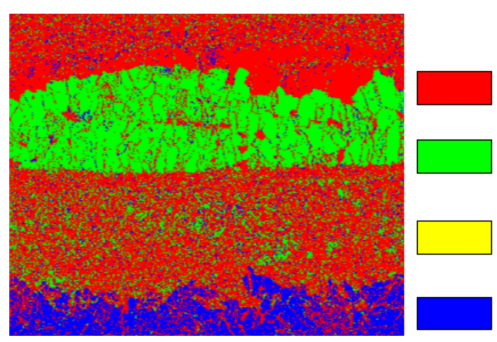

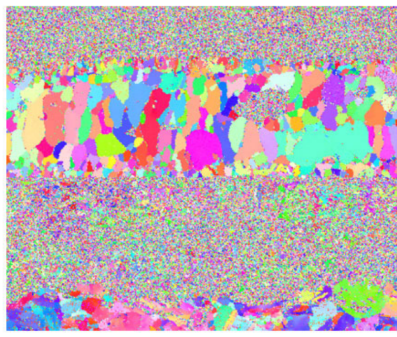

(b)

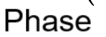

Hematite

Magnetite

Spinel

$\alpha-\mathrm{Fe}$

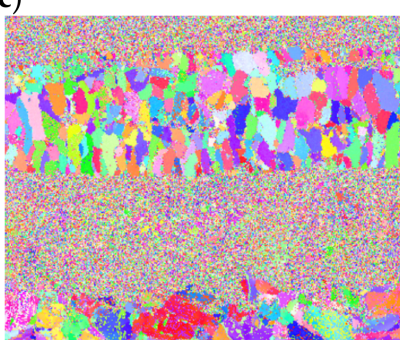

(e)

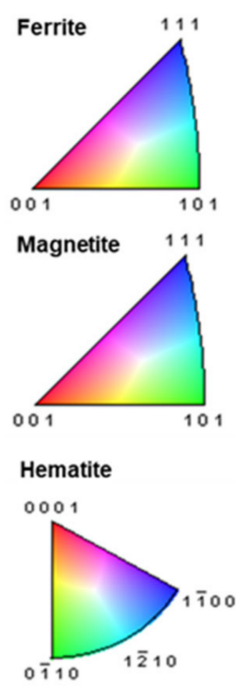

Magnetite

Hematite

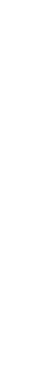

Phase
Hematite
Magnetite
Spinel
$\alpha-F e$
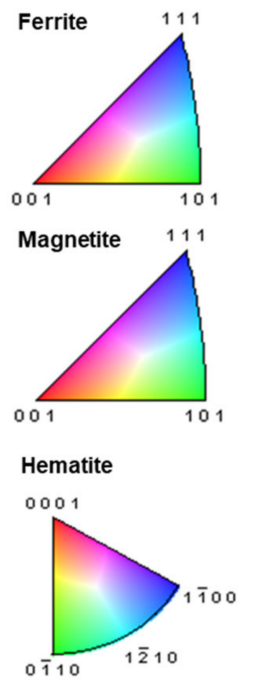

(f)

Figure 4. EBSD results of the oxidation scale of T91 test: (a) IQ map, (b) IPF with orientation map, (c) phase map of untreated specimens after $200 \mathrm{~h}$ steam exposure, (d) IQ map, (e) IPF with orientation map, and (f) phase map of SP-treated specimens after $200 \mathrm{~h}$ steam exposure. 
Figure 5 shows cross-sectional SEM micrographs of the untreated (a1-a4) and SPtreated (b1-b4) specimens after steam exposure at $650{ }^{\circ} \mathrm{C}$ for $100,600,800$, and $1000 \mathrm{~h}$. After steam exposure, the thickness of the scale formed on the untreated specimens increased rapidly with oxidation time. In contrast, the oxidation scale formed on the shot peened specimens was relatively stable and grew only slowly with increasing oxidation durations. In addition, numerous defects, such as voids and micro-cracks, formed between the $\mathrm{Fe}_{2} \mathrm{O}_{3}$ and the $\mathrm{Fe}_{3} \mathrm{O}_{4}$ layer in the untreated specimens, as shown in Figure 5(a1-a4). With a further increase of exposure time to $800 \mathrm{~h}$, exfoliation of the outer layer and breakage of the inner layer were observed in the untreated specimens as shown in Figure 5(a3). However, the shot peened specimens maintained a compact scale, with fewer defects during the entire steam exposure, Figure 5(b1-b4). The diffusion of iron beyond these defects is greatly retarded and thought to be the main reason for the separation of the outer layer. The process of the exfoliation of the outer layer progress is as Nishimura proposed [13].

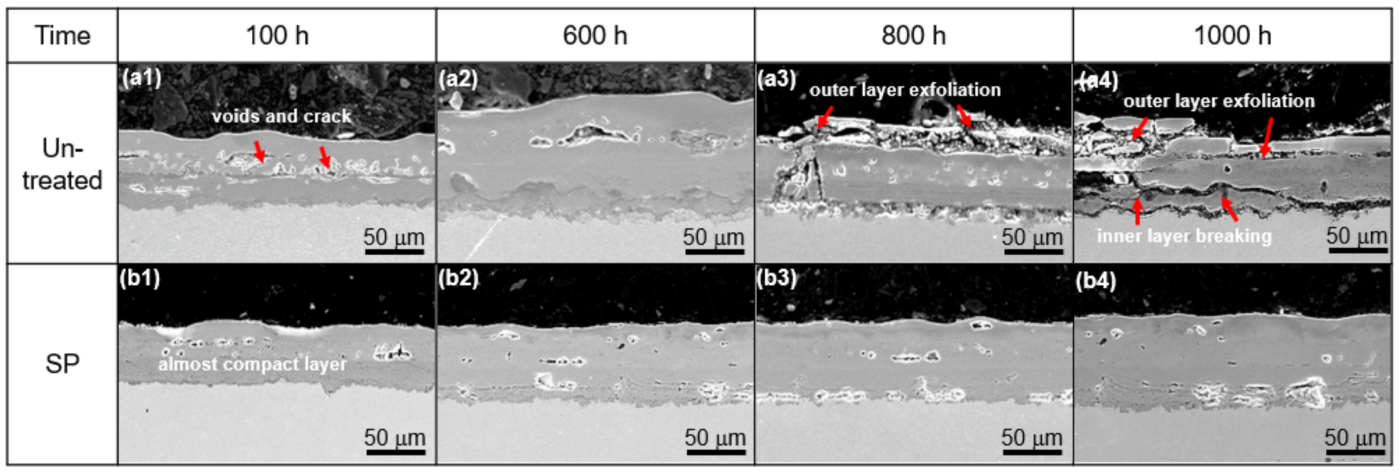

Figure 5. Cross-sectional SEM images of oxide scale after steam exposure of for various durations: (a1-a4) for untreated and (b1-b4) for shot peened specimens.

\section{Discussion}

\subsection{Evolution of Oxidation Scale}

Figure 6 shows a plot of the oxidation scale thickness in Table 3 as a function of oxidation duration. The abrupt decrease in the scale thickness of the untreated specimens at 800 and $1000 \mathrm{~h}$ are believed to be due to the exfoliation of the outer layer, as shown in Figure 5(a3,a4). In agreement with previous observations [14-17], parabolic oxidations kinetics were observed for both untreated and shot peened specimens. As can be seen in Figure 6, the experimental data points can be fit by a parabolic curve, represented by the following equation:

$$
\mathrm{d}^{2}=\mathrm{k}_{\mathrm{p}} \times \mathrm{t},
$$

where $\mathrm{d}$ is the total scale thickness, $\mathrm{kp}$ is the parabolic rate constant, and $\mathrm{t}$ is the oxidation time. The values of $\mathrm{kp}$ of untreated and shot peened specimens derived from best fits to the curve are $3 \times 10^{-7}$ and $1.5 \times 10^{-7} \mathrm{~mm}^{2} / \mathrm{min}$, respectively. It can be said that the growth rate of oxidation scale of shot peened specimens is much slower than that of untreated specimens at $650{ }^{\circ} \mathrm{C}$ steam exposure. 
Table 3. Oxidation scale layer thickness of untreated and shot peened T91 specimens after steam exposures of various durations (Fe-oxide refers to $\mathrm{Fe}_{2} \mathrm{O}_{3}$ and $\mathrm{Fe}_{3} \mathrm{O}_{4}$ combined).

\begin{tabular}{|c|c|c|c|c|c|c|}
\hline \multirow{2}{*}{$\begin{array}{l}\text { Exposure } \\
\text { Time } \\
\text { (h) }\end{array}$} & \multicolumn{2}{|c|}{$\begin{array}{c}\text { Total Scale } \\
\text { Thickness }(\mu \mathrm{m})\end{array}$} & \multicolumn{2}{|c|}{$\begin{array}{c}\text { Fe-Cr-O Layer } \\
\text { Thickness ( } \mu \mathrm{m})\end{array}$} & \multicolumn{2}{|c|}{$\begin{array}{l}\text { Fe-Oxide Layer } \\
\text { Thickness ( } \mu \mathrm{m})\end{array}$} \\
\hline & Untreated & SP & Untreated & SP & Untreated & SP \\
\hline 100 & $63.0 \pm 2.3$ & $49.0 \pm 2.5$ & $28.0 \pm 1.0$ & $18.4 \pm 1.8$ & $35.8 \pm 1.3$ & $30.6 \pm 1.2$ \\
\hline 200 & $72.8 \pm 1.6$ & $64.4 \pm 0.9$ & $30.5 \pm 0.8$ & $28.6 \pm 1.2$ & $42.3 \pm 1.3$ & $35.8 \pm 1.3$ \\
\hline 400 & $79.0 \pm 3.0$ & $67.4 \pm 4.0$ & $32.3 \pm 0.9$ & $31.1 \pm 0.8$ & $46.7 \pm 2.1$ & $36.3 \pm 1.0$ \\
\hline 600 & $102.1 \pm 2.9$ & $67.9 \pm 0.9$ & $35.0 \pm 1.2$ & $30.6 \pm 1.0$ & $67.1 \pm 2.3$ & $37.3 \pm 1.6$ \\
\hline 800 & $\begin{array}{l}57.4 \pm 1.1 \\
\text { (left over) }\end{array}$ & $68.9 \pm 2.1$ & $31.6 \pm 0.8$ & $30.3 \pm 1.2$ & $25.8 \pm 5.4$ & $38.6 \pm 1.9$ \\
\hline 1000 & $\begin{array}{l}67.2 \pm 5.8 \\
\text { (left over) }\end{array}$ & $70.1 \pm 2.4$ & $33.8 \pm 1.3$ & $31.1 \pm 0.9$ & $33.4 \pm 5.6$ & $39.0 \pm 1.8$ \\
\hline
\end{tabular}

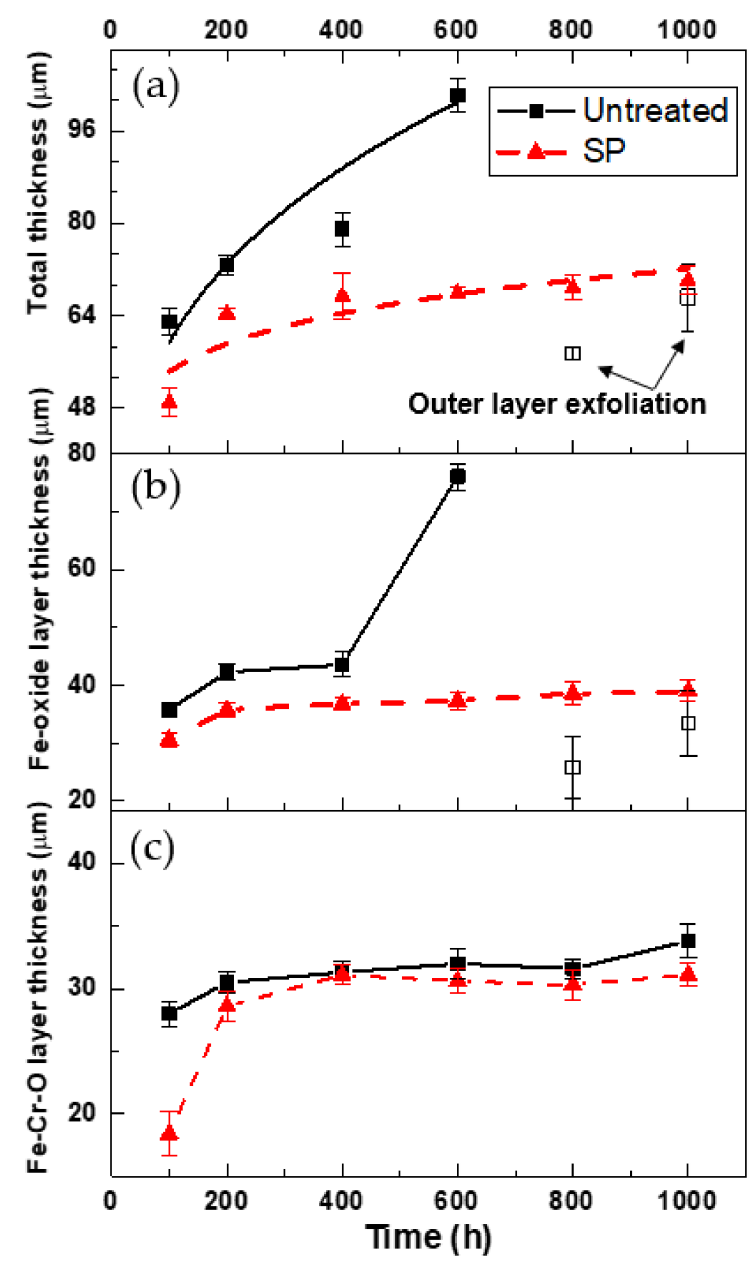

Figure 6. Oxidation scale thickness as a function of exposure time: (a) total layer, (b) outer Fe-oxide $\left(\mathrm{Fe}_{2} \mathrm{O}_{3}\right.$ and $\left.\mathrm{Fe}_{3} \mathrm{O}_{4}\right)$ layer, and (c) inner (Fe-Cr-O spinel) layer.

\subsection{Effect of Shot Peening}

Shot peening refines strain-induced grains, leading to a fine grain with a large fraction of grain boundaries on the peened surface. The fraction of low-angle grain boundaries in the surface area increased from $35.6 \%$ in the untreated specimen to $49.9 \%$ in the shot peened specimen calculated from Figure $2 \mathrm{~b}$, d. The grain size and grain boundaries determine the diffusion rates of elements during the formation of protective oxide layer. The effective 
diffusivity $\left(D_{\text {eff }}\right)$ of preferential nucleating elements is the sum of the lattice diffusivity $\left(D_{1}\right)$ and the diffusivity of the grain boundary $\left(\mathrm{D}_{\mathrm{GB}}\right)$, as proposed by Peng [18],

$$
D_{\text {eff }}=(1-f) \times D_{1}+f \times D_{G B}
$$

where $\mathrm{f}$ is the area proportion of the grain boundary. Assuming the grains are cubic, $\mathrm{f}=2 \delta / \mathrm{d}$ ( $\delta$ is the GB width and $\mathrm{d}$ the grain size). Considering that $\mathrm{D}_{\mathrm{GB}} \gg \mathrm{D}_{1}$, Equation (2) can be simplified as

$$
D_{\text {eff }}=D_{1}+2 \delta / d \times D_{G B},
$$

Thus, the effective diffusivity of $\mathrm{Cr}$ noticeably increases with decreasing grain size induced by shot peening through grain boundary diffusion.

Figure 7 shows cross-sectional SEM micrographs of untreated and shot peened specimens after 100 and $600 \mathrm{~h}$ steam exposure. Figure 8 shows cross-sectional EDS mapping micrographs of shot peened specimens after $600 \mathrm{~h}$ steam exposure. There is no $\mathrm{Cr}$-depleted zone apparent at the oxide-metal interface of the untreated specimen during the early stage of oxidation $(100 \mathrm{~h})$, which is totally different in the shot peened specimen. There, a Cr-depleted zone forms due to outward diffusion of $\mathrm{Cr}$ to form a $\mathrm{Cr}$-rich protective layer by decomposition of precipitate $\mathrm{M}_{23} \mathrm{C}_{6}$. This means, shot peening induced plenty of grain boundaries to provide more pathways for the outward diffusion of $\mathrm{Cr}$.

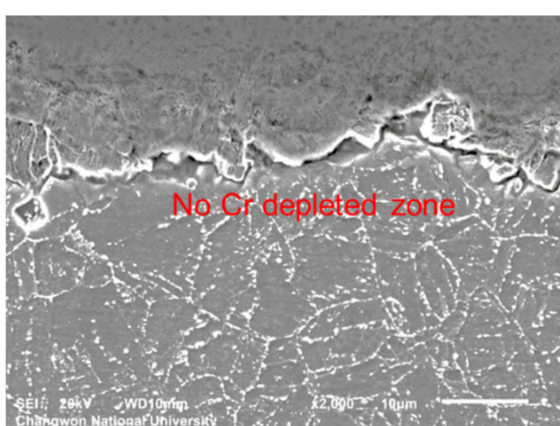

(a)

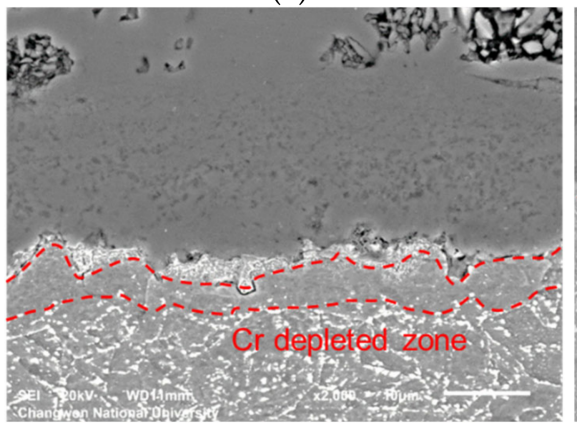

(c)

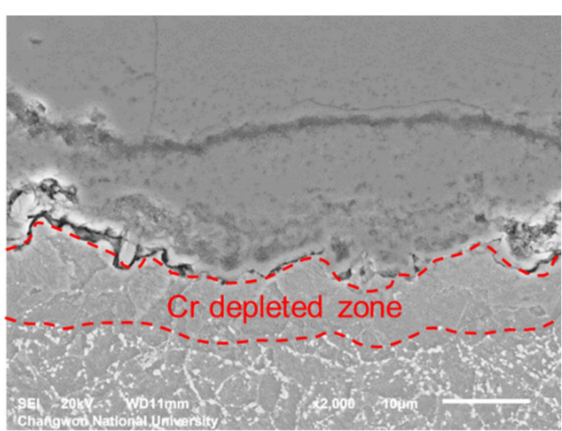

(b)

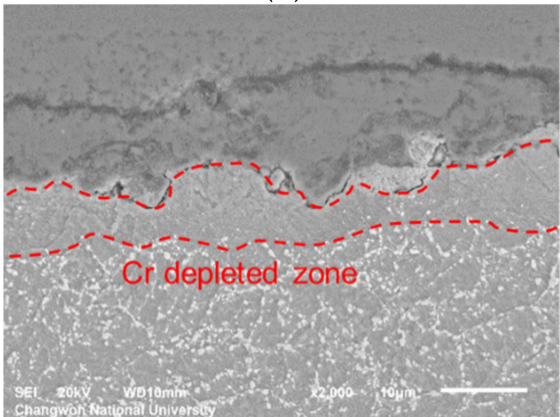

(d)

Figure 7. Cross-sectional SEM images of oxidation scale: (a) untreated $100 \mathrm{~h}$, (b) untreated $600 \mathrm{~h}$, (c) SP $100 \mathrm{~h}$, and (d) SP $600 \mathrm{~h}$. 


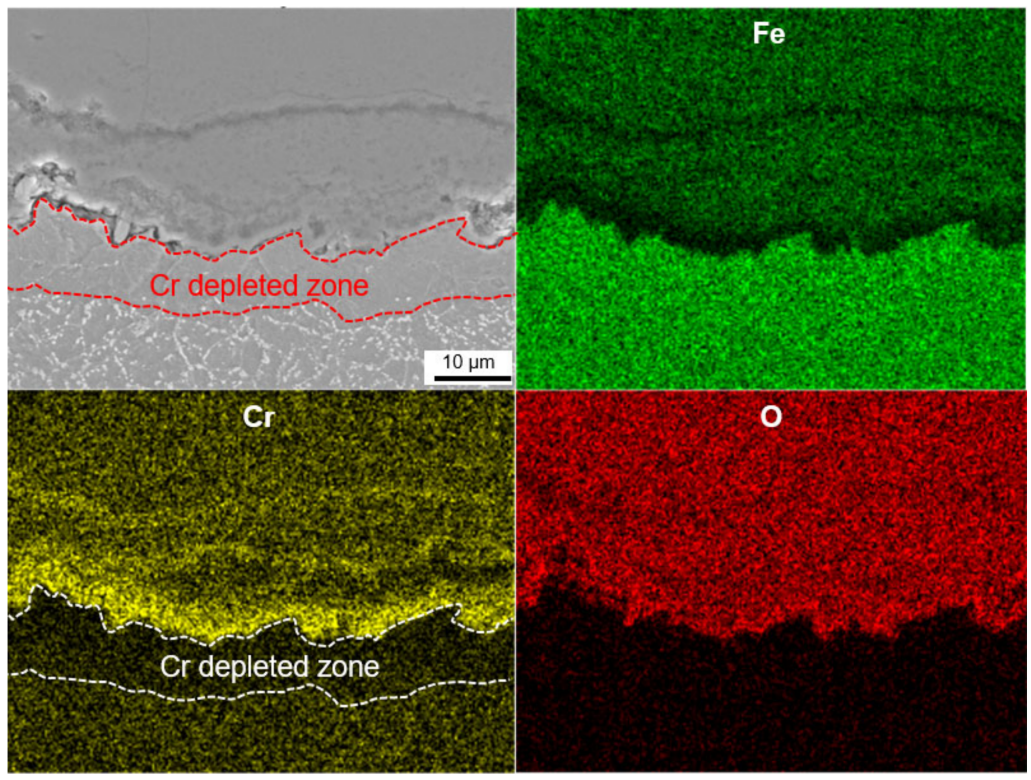

Figure 8. Cross-sectional SEM images of oxidation scale of SP-treated specimen after $600 \mathrm{~h}$ steam exposure.

\section{Conclusions}

In this work, the effects of shot peening on preventing the oxidation scale formed on T91 upon steam exposure were investigated. We reach the following conclusions:

1. Grain refinement occurs on the top surface of the 10-min shot peened specimen, for which the grain size is $\sim 3 \mu \mathrm{m}$, compared to the original grain size of $\sim 10 \mu \mathrm{m}$.

2. After 100-600 h steam exposure at $650{ }^{\circ} \mathrm{C}$, oxide scales formed on $\mathrm{T} 91$ specimens were identified as: an uppermost $\mathrm{Fe}_{2} \mathrm{O}_{3}$ layer, an $\mathrm{Fe}_{3} \mathrm{O}_{4}$ layer below, and an $\mathrm{FeCr}_{2} \mathrm{O}_{4}$ spinel layer. The total scale thickness of the SP and untreated specimens as measured at various steam exposure durations follows parabolic oxidation kinetics. Untreated specimens exhibit much larger scale thickness and faster scale growth rate than SP-treated specimens, indicating that shot peening improves oxidation resistance.

3. After steam exposure for $800-1000 \mathrm{~h}$ at $650{ }^{\circ} \mathrm{C}$, numerous voids and micro-cracks form between the $\mathrm{Fe}_{2} \mathrm{O}_{3}$ and $\mathrm{Fe}_{3} \mathrm{O}_{4}$ layers in the untreated specimens, resulting in partial exfoliation of the uppermost $\mathrm{Fe}_{2} \mathrm{O}_{3}$ layer. In contrast, the SP-treated specimens retain dense and compact oxidation scale with few voids or micro-cracks.

4. A Cr-depleted zone forms at the oxide-metal interface in the SP-treated specimen after $100 \mathrm{~h}$ steam exposure, in which decomposition of $\mathrm{M}_{23} \mathrm{C}_{6}$ precipitate is observed.

Author Contributions: Conceptualization, Y.H. and L.X.; methodology, L.X. and Y.H.; validation, Y.H., Y.K. and K.S.; formal analysis, L.X.; investigation, L.X.; resources, Y.K. and Y.H.; data curation, L.X.; writing—original draft preparation, L.X.; writing—review and editing, K.S.; visualization, L.X.; supervision, K.S.; project administration, Y.K. and Y.H.; funding acquisition, Y.K. All authors have read and agreed to the published version of the manuscript.

Funding: This work was supported by the Korea Institute of Energy Technology Evaluation and Planning (KETEP) and the Ministry of Trade, Industry, and Energy (MOTIE) of the Republic of Korea (no. 20161110100090). This work was partially supported by the National Research Foundation of Korea (NRF) grant funded by the Korea government (MSIT) (no. 2018R1A5A6075959).

Institutional Review Board Statement: Not applicable.

Informed Consent Statement: Not applicable.

Data Availability Statement: Not applicable.

Conflicts of Interest: The authors declare no conflict of interest. 


\section{References}

1. Fry, A.; Osgerby, S.; Wright, M. Oxidation of alloys in steam environments: A review. In NPL Report MATC; National Physical Laboratory: London, UK, 2002; Volume 90, pp. 45-89.

2. Shingledecker, J.P.; Pint, B.A.; Fry, A.T.; Wright, I.G. Managing Steam-Side Oxidation and Exfoliation in USC Boiler Tubes. Adv. Mater. Process. 2013, 171, 23-25.

3. Laverde, D.; Gomez-Acebo, T.; Castro, F. Continuous and cyclic oxidation of T91 ferritic steel under steam. Corros. Sci. 2004, 46, 613-631. [CrossRef]

4. Liu, G.; Wang, C.; Yu, F.; Tian, J. Evolution of oxide film of T91 steel in water vapor atmosphere at 750 ${ }^{\circ} \mathrm{C}$. Oxid. Met. 2014, 81 , 383-392. [CrossRef]

5. Chen, Y.; Sridharan, K.; Todd, A. Corrosion behavior of ferritic-martensitic steel T91 in supercritical water. Corros. Sci. 2006, 48, 2843-2854. [CrossRef]

6. Zhang, D.; Xu, J.; Zhao, G.; Guan, Y.; Li, M. Oxidation characteristic of ferritic-martensitic steel T91 in water-vapor atmosphere. Chin. J. Mater. Res. 2009, 22, 599-605.

7. Atkinson, A. Wagner theory and short circuit diffusion. Mater. Sci. Technol. 1988, 4, 1046-1051. [CrossRef]

8. He, Y.; Yang, C.W.; Lee, J.H.; Shin, K. Study of the Microstructural Evolution of Tempered Martensite Ferritic Steel T91 upon Ultrasonic Nanocrystalline Surface Modification. Appl. Microsc. 2015, 45, 170-176. [CrossRef]

9. Li, K.; Ma, H.; He, Y.; Chang, J.; Bae, S.Y.; Shin, K. Microstructural evolution and oxidation resistance of T92 boiler tube steel upon long-term supercritical steam test. Fusion Eng. Des. 2017, 125, 361-366. [CrossRef]

10. Ma, H.; He, Y.; Bae, S.Y.; Shin, K. Effect of shot peening on oxidation behavior of SS304H upon long term steam exposure. J. Nanosci. Nanotechnol. 2018, 18, 6167-6172. [CrossRef] [PubMed]

11. Naraparaju, R.; Christ, H.J.; Renner, F.U.; Kostka, A. Effect of shot-peening on the oxidation behaviour of boiler steels. Oxid. Met. 2011, 76, 233-245. [CrossRef]

12. Kurley, J.M.; Pint, B.A. The Effect of Shot Peening on Steam Oxidation of 304H Stainless Steel. Oxid. Met. 2020, 93, 159-174. [CrossRef]

13. Nishimura, N.; Komai, N.; Hirayama, Y.; Masuyama, F. Japanese experience with steam oxidation of advanced heat-resistant steel tubes in power boilers. Mater. High Temp. 2005, 22, 3-10. [CrossRef]

14. Downey, B.J.; Bermel, J.C.; Zimmer, P.J. Kinetics of the nickel-chlorine reaction at temperatures between 350 and $600{ }^{\circ} \mathrm{C}$. Corrosion 1969, 25, 502. [CrossRef]

15. Arıtegui, A.; Gomez-Acebo, T.; Castro, F. Steam oxidation of ferritic steels: Kinetics and microstructure. Bol. Soc. Esp. Ceram. Vidr. 2000, 39, 305.

16. Khanna, A.S.; Rodriguez, P.; Gananamoorthy, J.B. Oxidation kinetics, breakaway oxidation, and inversion phenomenon in 9Cr-1Mo steels. Oxid. Met. 1986, 26, 171. [CrossRef]

17. Vossen, J.P.T.; Gawenda, P.; Rahts, K.; Schorr, M.; Schutze, M. Limits of the oxidation resistance of several heat-resistant steels under isothermal and cyclic oxidation as well as under creep in air at $650^{\circ} \mathrm{C}$. Mater. High Temp. 1997, 14, 387. [CrossRef]

18. Peng, X.; Yan, J.; Zhou, Y.; Wang, F. Effect of grain refinement on the resistance of 304 stainless steel to breakaway oxidation in wet air. Acta Mater. 2005, 53, 5079-5088. [CrossRef] 